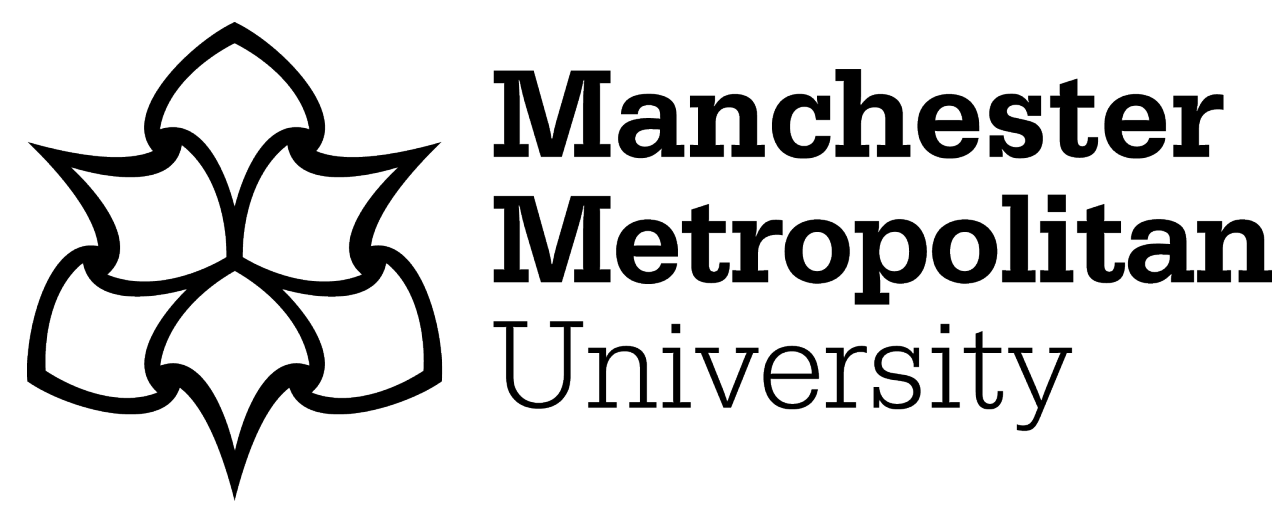

Ben-Naim, Micha, Palm, David W, Strickler, Alaina L, Nielander, Adam C, Sanchez, Joel, King, Laurie A ORCID logoORCID: https://orcid.org/00000002-0772-2378, Higgins, Drew C and Jaramillo, Thomas F (2020) A Spin Coating Method To Deposit Iridium-Based Catalysts onto Silicon for Water Oxidation Photoanodes. ACS Applied Materials \& Interfaces, 12 (5). pp. 5901-5908. ISSN 1944-8244

Downloaded from: https://e-space.mmu.ac.uk/624942/

Version: Accepted Version

Publisher: American Chemical Society (ACS)

DOI: https://doi.org/10.1021/acsami.9b20099

Please cite the published version 


\section{A Spin Coating Method to Deposit Iridium-Based Catalysts onto Silicon for Water Oxidation}

\section{Photoanodes}

Micha Ben-Naim ${ }^{\dagger}$, David W. Palm ${ }^{\dagger}$,Alaina L. Strickler ${ }^{\dagger}$,Adam C. Nielander ${ }^{\dagger}$, Joel Sanchez ${ }^{\dagger}$, Laurie A. King ${ }^{\dagger, *}$, Drew C. Higgins ${ }^{\dagger, \xi,}{ }^{*}$, Thomas F. Jaramillo ${ }^{\dagger, *}$

AUTHOR ADDRESS

${ }^{\dagger}$ Department of Chemical Engineering, Stanford University, 443 Via Ortega, Stanford, California 94305, United States

${ }^{\sharp}$ Faculty of Science and Engineering, Manchester Metropolitan University, Chester Street, Manchester, M1 5GD, U.K.

${ }^{\S}$ Department of Chemical Engineering, McMaster University, Hamilton, Ontario, Canada L8S $4 \mathrm{~L} 8$

\section{KEYWORDS}

Photoelectrochemical water splitting, iridium oxide, oxygen evolution, photoanodes, spin coating 


\section{ABSTRACT}

Silicon has shown promise for use as a small band gap (1.1 eV) absorber material in photoelectrochemical (PEC) water-splitting. However, the limited stability of silicon in acidic electrolyte requires the use of protection strategies coupled with catalysts. Herein, spin coating is used as a versatile method to directly coat silicon photoanodes with an $\mathrm{IrO}_{\mathrm{x}}$ oxygen evolution reaction (OER) catalyst, reducing the processing complexity compared to conventional fabrication schemes. Biphasic strontium chloride/iridium oxide $\left(\mathrm{SrCl}_{2}: \mathrm{IrO}_{\mathrm{x}}\right)$ catalysts are also developed, and both catalysts form photoactive junctions with silicon and demonstrate high photoanode activity. The iridium oxide photoanode displays a photocurrent onset at $1.06 \mathrm{~V}$ vs. RHE, while the $\mathrm{SrCl}_{2}$ : $\mathrm{IrO}_{\mathrm{x}}$ photoanode onsets earlier at $0.96 \mathrm{~V}$ vs. RHE. The differing potentials are consistent with the observed photovoltages of $0.43 \mathrm{~V}$ and $0.53 \mathrm{~V}$ for the $\mathrm{IrO}_{\mathrm{x}}$ and $\mathrm{SrCl}_{2}: \mathrm{IrO}_{\mathrm{x}}$, respectively.

By measuring the oxidation of a reversible redox couple, $\mathrm{Fe}(\mathrm{CN})_{6}{ }^{3-/ 4-}$, we compare the charge carrier extraction of the devices and show that the addition of $\mathrm{SrCl}_{2}$ to the $\mathrm{IrO}_{\mathrm{x}}$ catalyst improves the silicon-electrolyte interface compared to pure $\mathrm{IrO}_{\mathrm{x}}$. However, the durability of the strontiumcontaining photoanode remains a challenge, with its photocurrent density decreasing by $90 \%$ over 4 hours. The $\mathrm{IrO}_{\mathrm{x}}$ photoanode, on the other hand, maintained a stable photocurrent density over this timescale. Characterization of the as-prepared and post-tested material structure via Auger electron spectroscopy identifies catalyst film cracking and delamination as the primary failure modes. We propose that improvements to catalyst adhesion should further the viability of spin coating as a technique for photoanode preparation.

\section{TOC GRAPHIC}




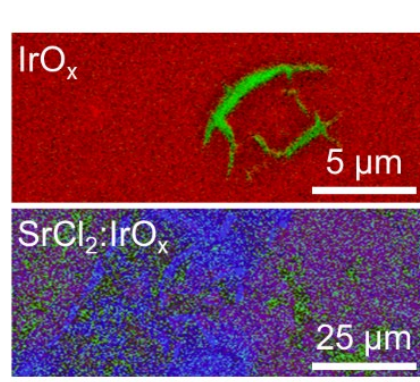

AES Map: Ir, Sr, Si

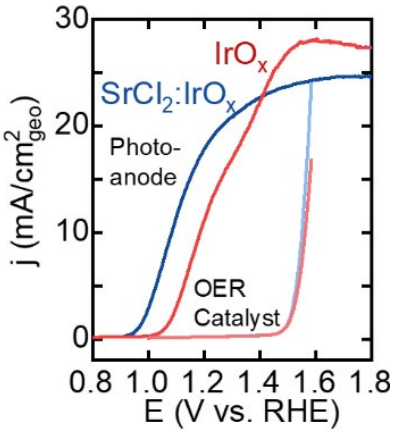

TEXT

\section{Introduction}

Photoelectrochemical (PEC) water splitting is an attractive technology that uses sunlight to split water into hydrogen and oxygen, providing a storable chemical fuel to supplement intermittent renewable energy sources. ${ }^{1-4}$ For PEC to become a viable means of sustainable hydrogen generation, the device must be highly efficient, durable, and cost-effective. ${ }^{5}$ Tandem-absorber devices, in which two semiconductor absorbers are stacked in series, are particularly relevant as they can achieve the high voltage needed to split water while generating a high photocurrent. ${ }^{1,2}$ To maximize device efficiency, photoelectrode materials need to be paired with an effective oxygen evolution reaction (OER) or hydrogen evolution reaction (HER) catalyst while minimizing parasitic light absorption. ${ }^{6}$ Often an additional protection layer such as a metal ${ }^{7,8}$, metal oxide ${ }^{9,10}$, or carbon nanomaterial $1^{11,12}$ is needed to prevent semiconductor corrosion by insulating the semiconductor from electrolyte contact. A range of photocathodes with varied semiconductor and catalyst materials have demonstrated high activity toward HER and stability in acidic electrolyte. ${ }^{6}$ In contrast, there are far fewer active stable photoanodes known due to the limited stability of most catalysts and semiconductors in acidic electrolyte at the oxidizing potentials of the OER. ${ }^{6,13}$ 
Silicon is a desirable absorber for photoanodes due to its low cost, robust fabrication process, favorable band alignment with the OER, and near-ideal bandgap $(1.1 \mathrm{eV})$ to pair with a widebandgap absorber. ${ }^{1,6}$ Several reports have shown that ultrathin $\mathrm{TiO}_{2}$ coatings can effectively protect silicon from passivation and form efficient photoanodes when coated with an iridium OER catalyst. ${ }^{9,10,14-21}$ A recent report demonstrated that $\mathrm{IrO}_{\mathrm{x}} / \mathrm{Ir}$ sputtered onto $\mathrm{p}^{+} \mathrm{n}-\mathrm{Si}$ without an additional protection layer produced $0.5-0.62 \mathrm{~V}$ of photovoltage and effectively protected the semiconductor for 18 hours of PEC operation with only moderate current loss. ${ }^{22}$ These protecting strategies utilized complex deposition techniques such as atomic layer deposition (ALD) and sputtering, which require sub-nanometer control of the protection layer thickness and structure to avoid performance losses due to increased device resistance in the $\mathrm{TiO}_{2}{ }^{9}$ or decreased stability of the $\mathrm{IrO}_{\mathrm{x}}{ }^{22}$ To facilitate the scale-up of PEC water-splitting, it is desirable to reduce processing complexity and decrease the sensitivity of anode performance on structural variables while maintaining high activity and long-term durability.

Of the known OER catalysts, only iridium oxide-based materials have demonstrated long-term stability at oxidizing potentials in corrosive acidic media. ${ }^{3,23-26}$ Herein, we focus on using a simple spin coating technique to deposit $\mathrm{IrO}_{\mathrm{x}}$ OER electrocatalysts directly onto a silicon absorber to fabricate a photoanode junction, thereby minimizing the number and complexity of fabrication steps. In addition, recent work has shown that crystalline $\mathrm{SrIrO}_{3}$ provides the highest known OER activity in acid on a catalyst surface-area basis. ${ }^{27,28}$ However, the pulsed laser deposition (PLD) synthesis for these $\mathrm{SrIrO}_{3}$ catalysts requires an atomically flat, lattice-matched substrate as well as high deposition temperatures of $650^{\circ} \mathrm{C}$, which limit the application of $\mathrm{SrIrO}_{3}$ towards photoanodes. 
Instead, this report develops a solution processing technique to combine iridium oxide with strontium for use as an OER catalyst.

In this work we report a spin coating method to deposit a pure $\mathrm{IrO}_{\mathrm{x}}$ catalyst film onto silicon for use as a photoanode, reducing the processing complexity of conventional photoanodes. Strontium chloride-modified iridium oxide catalysts are also developed, and both catalyst films are characterized in terms of morphology, chemical distribution, and crystallography. The performance and stability of the photoanodes were tested for PEC water oxidation, and the effects of strontium on the $\mathrm{Si} /$ catalyst interface were evaluated using a reversible redox couple to decouple the catalysis from interfacial charge transport. Post-PEC testing characterization is used to identify degradation mechanisms. This study demonstrates the utility of spin coating as a simple, low cost fabrication technique to directly coat catalyst materials onto silicon photoanodes for PEC watersplitting. The photoanodes deliver high photovoltages that are comparable to those generated by state of the art ALD-protected Si photoanodes. ${ }^{9,19-21}$ The addition of strontium is shown to improve the charge carrier extraction properties of the silicon-catalyst-electrolyte junction, but the heterogeneous nature of the catalyst accelerates instability, which is associated with poor adhesion. Solution-processed photoanode materials have not previously been widely explored, and this work provides routes to simplify fabrication schemes for both silicon and other photoanodes, while the insight into degradation mechanisms can help guide the design of materials with improved stability.

\section{Results \& Discussion}

\section{$\underline{\text { Catalyst Structure }}$}


We synthesized photoanodes with a pure iridium oxide OER catalyst on $\mathrm{Si}$ architecture $\left(\operatorname{IrO} \mathrm{x}_{\mathrm{x}} \mid \mathrm{n}\right.$ Si) by spin coating a solution of iridium acetate onto a Si substrate followed by an air calcination at $250^{\circ} \mathrm{C} .{ }^{29-31}$ Strontium-modified iridium oxide-coated $\mathrm{Si}$ photoanodes $\left(\mathrm{SrCl}_{2}: \mathrm{IrO}_{\mathrm{x}} \mid \mathrm{n}\right.$-Si) were synthesized in an identical manner to $\mathrm{IrO}_{\mathrm{x}}$ except the spin coating solution contained both iridium acetate and strontium chloride. Detailed procedures can be found in the materials and methods section. Scanning electron microscopy (SEM) and Auger electron spectroscopy (AES) were used to characterize the morphology and elemental distribution of both materials (Figure 1). Crosssectional SEM imaging demonstrates that the $\mathrm{IrO}_{\mathrm{x}}$ coating has a fairly uniform morphology and a thickness of $45 \mathrm{~nm}$ (Figure 1a). Top-down SEM confirms this general uniformity, although there are some cracks in the surface on the order of 0.5-5 $\mu \mathrm{m}$ in length (Figure 1b). Auger electron spectroscopy (AES) mapping indicates that the cracks go through the entirety of the spin-coated film and expose the bare silicon substrate (Figure 1c, S2). The X-ray diffractogram (Figure 2a) shows only broad peaks corresponding to rutile $\mathrm{IrO}_{2}$, indicating that the iridium oxide is primarily amorphous, which is consistent with previous reports of solution-processed iridium oxide calcined at $250{ }^{\circ} \mathrm{C}^{29-31}$

The strontium-containing $\mathrm{IrO}_{\mathrm{x}}$ film, referred to here as $\mathrm{SrCl}_{2}: \mathrm{IrO}_{\mathrm{x}}$, is less uniform and conformal than the $\mathrm{IrO}_{\mathrm{x}}$ film (Figure 1d). The morphology of the $\mathrm{SrCl}_{2}$ : $\mathrm{IrO}_{\mathrm{x}}$ as seen by $\mathrm{SEM}$ contains many macroscopic defects (Figure 1e, S1), with large stripes around $30 \mu \mathrm{m}$ wide and many smaller cracks of less than $5 \mu \mathrm{m}$. AES mapping shows that there is phase segregation between $\mathrm{Sr}$ and $\mathrm{Ir}$ (Figure 1f), with the $30 \mu \mathrm{m}$ stripe containing mostly $\mathrm{Sr}$ and all of the iridium residing in the remaining film area. Some of the small cracks on the order of 0.5-5 $\mu \mathrm{m}$ expose the Si substrate. Residual $\mathrm{Cl}$ species from the $\mathrm{SrCl}_{2}$ precursor are co-located with the Sr (Figure S3). The co- 
location of the $\mathrm{Sr}$ and $\mathrm{Cl}$ observed via $\mathrm{AES}$ suggests that there is a $\mathrm{SrCl}_{2}$ phase separate from $\mathrm{IrO}_{\mathrm{x}}$. X-ray diffraction results (Figure 2b) confirm the presence of $\mathrm{SrCl}_{2}$, where the main diffraction peaks for the $\mathrm{SrCl}_{2}: \mathrm{IrO}_{\mathrm{x}}$ film correspond to $\mathrm{SrCl}_{2} \cdot 6 \mathrm{H}_{2} \mathrm{O}$, the thermodynamically stable hydrate of $\mathrm{SrCl}_{2}$ at room temperature. ${ }^{32}$ There are weak, broad peaks corresponding to rutile $\mathrm{IrO}_{2}$, indicating that the iridium oxide in $\mathrm{SrCl}_{2}: \mathrm{IrO}_{\mathrm{x}}$ is largely amorphous and phase segregated from $\mathrm{SrCl}_{2}$. The $\mathrm{IrO}_{2}$ diffraction peaks for $\mathrm{SrCl}_{2}: \mathrm{IrO}_{\mathrm{x}}$ are much weaker than those for $\mathrm{IrO}_{\mathrm{x}}$, suggesting that the iridium oxide is less crystalline in the strontium-containing catalyst film.
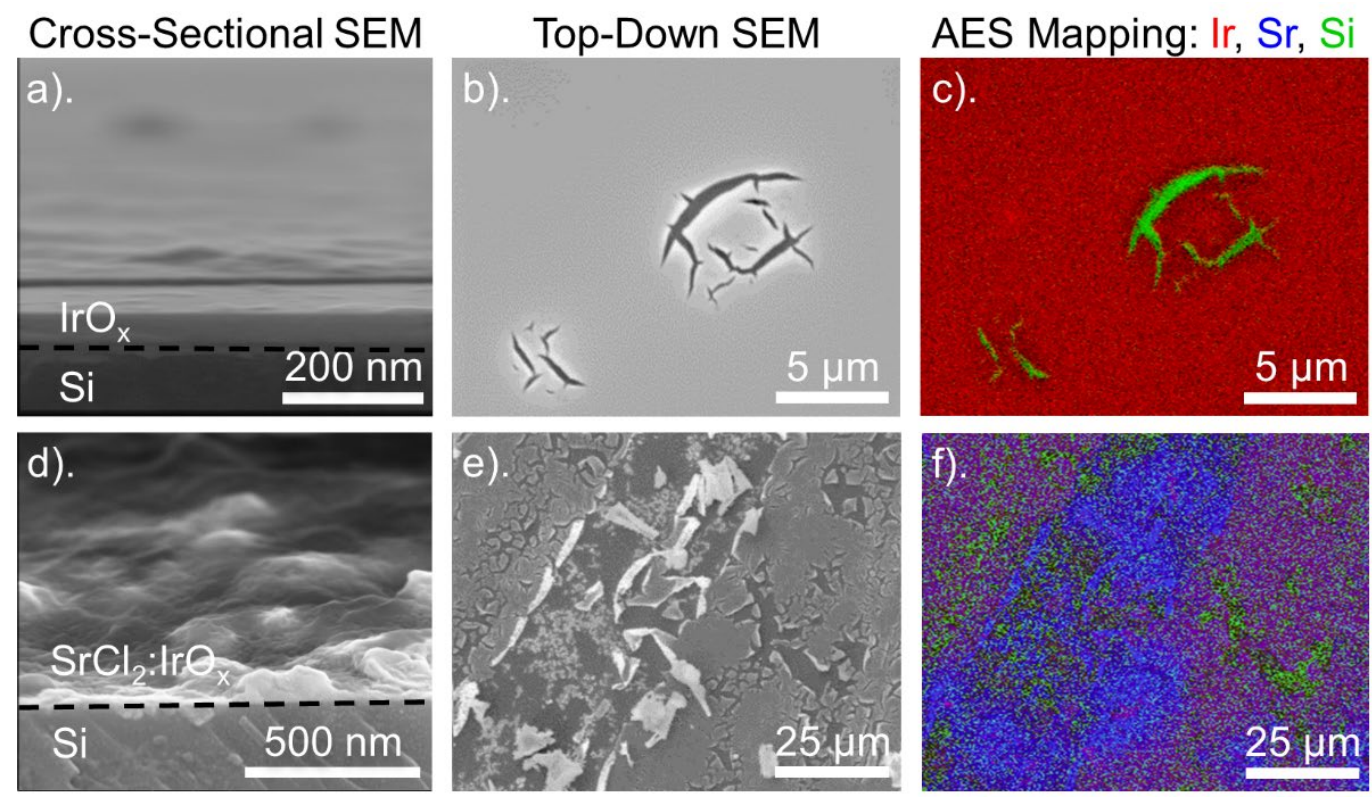

Figure 1. Photoanode characterization of $\mathrm{IrO}_{\mathrm{x}} \mid \mathrm{n}-\mathrm{Si}(\mathrm{a}-\mathrm{c})$ and $\mathrm{SrCl}_{2}: \mathrm{IrO}_{\mathrm{x}} \mid \mathrm{n}-\mathrm{Si}(\mathrm{d}-\mathrm{f})$. Cross-sectional SEM $(a, d)$ shows that the $\mathrm{IrO}_{\mathrm{x}}$ catalyst has a uniform morphology, while the $\mathrm{SrCl}_{2}: \mathrm{IrO}_{\mathrm{x}}$ has greater surface roughness. Dashed lines indicate the boundary between the catalyst film and the Si substrate. Top-down SEM (b,e) shows cracking and heterogeneity in the films. AES mapping (c,f) of Ir (red), Sr (blue), and Si (green) shows that there is exposed silicon in the cracks for both catalysts, while there is extensive phase segregation in the $\mathrm{SrCl}_{2}: \mathrm{IrO}_{\mathrm{x}}$ coating. 

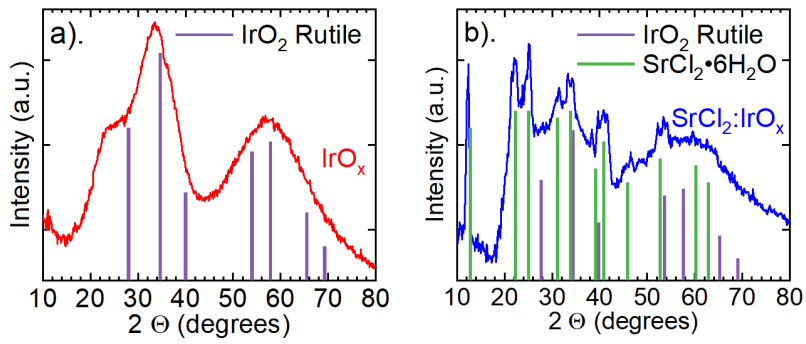

Figure 2. X-ray diffractograms (background subtracted) of $\mathrm{IrO}_{\mathrm{x}}(\mathrm{a})$ and $\mathrm{SrCl}_{2}: \mathrm{IrO}_{\mathrm{x}}$ (b). The broad diffraction peaks for $\mathrm{IrO}_{\mathrm{x}}$ indicate that the material is mostly amorphous, and the limited crystallinity comes from rutile $\mathrm{IrO}_{2}$. The $\mathrm{SrCl}_{2}: \mathrm{IrO}_{\mathrm{x}}$ film has $\mathrm{SrCl}_{2} \bullet 6 \mathrm{H}_{2} \mathrm{O}$ features, suggesting phase segregated $\mathrm{SrCl}_{2} \bullet 6 \mathrm{H}_{2} \mathrm{O}$. Reference patterns used: 00-015-0870 ( $\mathrm{IrO}_{2}$ rutile), 04-010-2886 $\left(\mathrm{SrCl}_{2} \bullet 6 \mathrm{H}_{2} \mathrm{O}\right)$. The raw XRD patterns can be seen in Figure $\mathrm{S} 4$.

To investigate phase segregation between $\mathrm{IrO}_{\mathrm{x}}$ and $\mathrm{SrCl}_{2}$ in $\mathrm{SrCl}_{2}: \mathrm{IrO}_{\mathrm{x}}, \mathrm{SEM}$ was performed after each step of the deposition process: (1) after spin coating only (Figure S5a); (2) following spin coating and a $50{ }^{\circ} \mathrm{C}$ hot plate treatment (Figure S5b); and lastly (3) the end of fabrication spin coating, hot plate treatment, and calcination at $250{ }^{\circ} \mathrm{C}$ (Figure S5c). Apparent phase segregation and cracking are visible immediately after spin coating, indicating that this process likely induces phase segregation between $\mathrm{Sr}$ and $\mathrm{Ir}$, which is retained during the heat treatments. During the spin coating procedure, $\mathrm{SrCl}_{2}$ and $\mathrm{Ir}\left(\mathrm{CH}_{3} \mathrm{COOH}\right)_{3}$ are dissolved in $5 \%$ v/v water in ethanol to facilitate both solubility of $\mathrm{SrCl}_{2}$ and fast evaporation during the spin coating process. We note that the solubility of $\mathrm{SrCl}_{2}$ is $\sim 20 \mathrm{~g} / \mathrm{L}(0.11 \mathrm{M})$ in $5 \%$ water in ethanol, as opposed to $>500 \mathrm{~g} / \mathrm{L}(>3.2 \mathrm{M})$ in water. ${ }^{32}$ We postulate that the low solubility of $\mathrm{SrCl}_{2}$ in ethanol drives the phase segregation between $\mathrm{IrO}_{\mathrm{x}}$ and $\mathrm{SrCl}_{2} \bullet 6 \mathrm{H}_{2} \mathrm{O}$ in the highly heterogeneous $\mathrm{SrCl}_{2}: \mathrm{IrO}_{\mathrm{x}}$ film. As the solvent film begins to evaporate during spin coating, the $\mathrm{Sr}$ and $\mathrm{Ir}$ precursors become 
increasingly concentrated, potentially causing the $\mathrm{SrCl}_{2}$ to become supersaturated and thus precipitate out of solution. ${ }^{33,34}$ This rapid precipitation of $\mathrm{SrCl}_{2}$ likely leads to the striped and heterogeneous morphology seen in Figure 1e. This effect has been previously been observed in substituted fullerene films deposited by spin coating, where different functional groups on solvated fullerenes change the solubility and greatly impact the film morphology. ${ }^{35}$

\section{$\underline{\text { Photoelectrochemical Testing }}$}

\section{i. Photoanode Activity}

The photoelectrochemical behavior of $\mathrm{IrO}_{\mathrm{x}} \mid \mathrm{n}-\mathrm{Si}$ and $\mathrm{SrCl}_{2}: \mathrm{IrO}_{\mathrm{x}} \mid \mathrm{n}-\mathrm{Si}$ were evaluated in $0.5 \mathrm{M}$ $\mathrm{H}_{2} \mathrm{SO}_{4}$ electrolyte under one-sun illumination and in the dark via cyclic voltammetry (CV) (Figure 3a,c). Both catalyst coatings formed effective junctions with silicon, as is evidenced by the photocurrent onset potential of $1.06 \mathrm{~V}$ vs. RHE for $\mathrm{IrO}_{\mathrm{x}} \mid \mathrm{n}-\mathrm{Si}$ and $0.96 \mathrm{~V}$ vs. RHE for $\mathrm{SrCl}_{2}: \mathrm{IrO}_{\mathrm{x}} \mid \mathrm{n}-$ Si. The current onset potential is defined as the potential required to reach a threshold current density of $1 \mathrm{~mA} / \mathrm{cm}^{2}$. Both photoanodes exhibit photocurrent onset potentials negative of the reversible potential for OER (1.23 V vs. RHE). The native $\mathrm{SiO}_{2}$ layer $(1.8 \mathrm{~nm})$ is thin enough to allow for hole tunneling, consistent with prior reports on $\mathrm{n} \mathrm{Si}$ photoanodes with thin $\mathrm{SiO}_{2}$ and/or $\mathrm{TiO}_{2}$ layers. ${ }^{19,36,37}$ The $\mathrm{SrCl}_{2}: \mathrm{IrO}_{\mathbf{x}} \mid \mathrm{n}-\mathrm{Si}$ anode has a slightly higher fill factor than $\mathrm{IrO}_{\mathbf{x}} \mid \mathrm{n}-\mathrm{Si}$, indicating that it has a lower resistance to charge transport across the Si-catalyst-electrolyte interface, assuming both photoanodes have similar catalysis and given the identical semiconductors. The dark current for both photoanodes is negligible across the potential range scanned. To understand the difference in performance between these two photoanode systems without complication from the silicon absorber or rectifying semiconductor-catalyst junction, we tested the OER performance of catalyst films deposited onto degenerately doped silicon $\left(\mathrm{p}^{+}-\mathrm{Si}\right)$. 
The strontium-containing catalyst has slightly higher raw catalytic activity than $\mathrm{IrO}_{\mathrm{x}}$ alone as seen in the potential required to reach a current density of $10 \mathrm{~mA} / \mathrm{cm}^{2}$, a common metric of OER activity. ${ }^{24,25} \mathrm{SrCl}_{2}: \mathrm{IrO}_{\mathrm{x}} \mid \mathrm{p}^{+}$-Si requires $1.55 \mathrm{~V}$ vs. RHE ( $0.32 \mathrm{~V}$ of overpotential) to generate 10 $\mathrm{mA} / \mathrm{cm}^{2}$ of current density, while $\mathrm{IrO}_{\mathrm{x}} \mid \mathrm{p}^{+}$-Si requires $1.56 \mathrm{~V}$ vs. RHE $(0.33 \mathrm{~V}$ of overpotential $)$. Thus, the addition of strontium chloride to the $\mathrm{IrO}_{\mathrm{x}}$ OER catalyst decreases the overpotential required to reach $10 \mathrm{~mA} / \mathrm{cm}^{2}$ by $0.01 \mathrm{~V}$.

One key metric of photoanode performance is the photovoltage $\left(\mathrm{V}_{\mathrm{ph}}\right)$, which is calculated as the difference in the potential of current onset between the photoanode and the corresponding dark electrocatalyst. ${ }^{19}$ Notably, the photovoltage of the $\mathrm{SrCl}_{2}: \mathrm{IrO}_{\mathrm{x}} \mid \mathrm{n}-\mathrm{Si}$ is $0.53 \mathrm{~V}$, or $0.10 \mathrm{~V}$ greater than that of the $\mathrm{IrO}_{\mathrm{x}} \mid \mathrm{n}-\mathrm{Si}$ system $(0.43 \mathrm{~V})$.
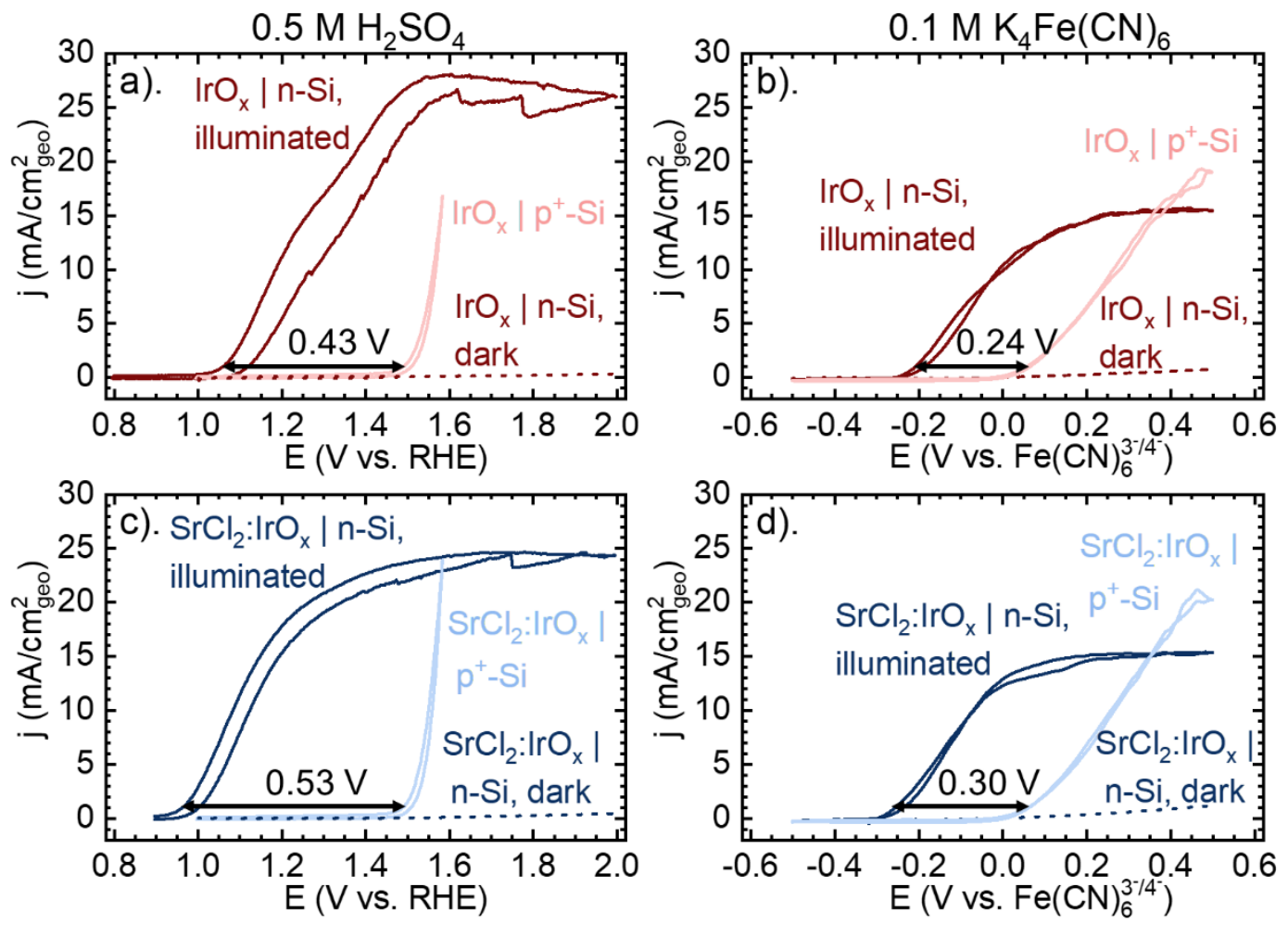
Figure 3. Photoelectrochemical testing results. Water oxidation testing $(a, c)$ is conducted in 0.5 $\mathrm{M} \mathrm{H}_{2} \mathrm{SO}_{4}$. CVs in $0.1 \mathrm{M} \mathrm{Fe}(\mathrm{CN})_{6}^{3-/ 4-}(\mathrm{b}, \mathrm{d})$ decouple catalytic performance from light absorption and charge transport. Photovoltage $\left(\mathrm{V}_{\mathrm{ph}}\right)$ values are calculated by the difference in potential of current onset between the anodic sweeps of the n-Si photoanode and corresponding OER catalyst. The black arrows indicate the two current onset potentials, where the line length represents the $\mathrm{V}_{\mathrm{ph}}$, noted above each arrow. All CVs are measured with a scan rate of $10 \mathrm{mV} / \mathrm{s}$.

PEC testing was also conducted in a solution of $0.1 \mathrm{M} \mathrm{K}_{4} \mathrm{Fe}(\mathrm{CN})_{6}$ and $1 \mathrm{mM} \mathrm{K}{ }_{3} \mathrm{Fe}(\mathrm{CN})_{6}($ Figure $3 b, d)$, a reversible redox couple, to decouple catalytic effects from light absorption and charge separation. ${ }^{20}$ Both catalyst films deposited onto $\mathrm{p}^{+}-\mathrm{Si}$ substrates showed similar J-V characteristics, consistent with the expected facile one-electron redox process at a conductive substrate. $\mathrm{SrCl}_{2}: \mathrm{IrO}_{\mathrm{x}} \mid \mathrm{n}-\mathrm{Si}$ gave $0.30 \mathrm{~V}$ of $\mathrm{V}_{\mathrm{ph}}$ during ferrocyanide oxidation, compared to $0.24 \mathrm{~V}$ for $\mathrm{IrO}_{\mathrm{x}} \mid \mathrm{p}^{+}-$ Si. The photoanodes produced less photovoltage during ferrocyanide oxidation than for water oxidation, which suggests that the electrolyte redox couple is in ionic contact with the Si-catalyst junction. Nevertheless, $\mathrm{SrCl}_{2}: \mathrm{IrO}_{\mathrm{x}} \mid n-\mathrm{Si}$ generates a higher $\mathrm{V}_{\mathrm{ph}}$ than $\mathrm{IrO}_{\mathrm{x}} \mid \mathrm{n}-\mathrm{Si}$ under both OER and $\mathrm{Fe}(\mathrm{CN}) 6^{3-/ 4-}$ conditions. The photovoltage measurements are supported by the open circuit potential (OCP) in the dark and under illumination, measured in both sulfuric acid and potassium ferrocyanide electrolytes measured in the dark and under illumination (Figure S8). ${ }^{38}$ The lightlimited photocurrent is approximately the same for both $\mathrm{IrO}_{\mathrm{x}} \mid \mathrm{n}-\mathrm{Si}$ and $\mathrm{SrCl}_{2}: \mathrm{IrO}_{\mathrm{x}} \mid \mathrm{n}-\mathrm{Si}$, around 15 $\mathrm{mA} / \mathrm{cm}^{2}$, meaning that light absorption in the two catalyst films is similar. Thus, we postulate that $\mathrm{SrCl}_{2}: \mathrm{IrO}_{\mathrm{x}}$ facilitates improved charge carrier transport across the Si-catalyst-electrolyte interface compared to $\mathrm{IrO}_{\mathrm{x}}$, leading to its improved photovoltage. Photoanodes with thinner catalyst films than those measured in Figures 1-5 were also tested, exhibiting a higher potential of current onset 
and lower $V_{p h}$ than the thickest films, likely due to differences in catalyst performance and interfacial charge transport (Figure S9).

Interestingly, after testing the films for three cyclic voltammetry cycles under illumination, XPS measurements indicate that the Ir near the surface becomes more oxidized in both photoanode architectures and that $\mathrm{SrCl}_{2}$ dissolves from the $\mathrm{SrCl}_{2}: \mathrm{IrO}_{\mathrm{x}}$ film in the surface region (Figure $\mathrm{S} 6$, S7). Despite the dissolution of $\mathrm{SrCl}_{2}$, the photoanodes still produce stable current over the timescale of three $\mathrm{CV}$ cycles. Because $\mathrm{SrCl}_{2}$ is not present in the catalyst during PEC operation, this salt likely plays little direct role in the improved performance of the photoanodes. Instead, we propose that the rough, porous morphology of the $\mathrm{SrCl}_{2}: \mathrm{IrO}_{\mathrm{x}}$ coating improves the electronic interface with $\mathrm{Si}$ and charge transport to the electrolyte over the more planar $\mathrm{IrO}_{\mathrm{x}}$. Prior experimental and theoretical studies on $\mathrm{WO}_{3}$ semiconductors coated with $\mathrm{IrO}_{2}$ catalyst films showed that conformal $\mathrm{IrO}_{2}$ coatings formed a junction with $\mathrm{WO}_{3}$ that resulted in poor interfacial charge transport and thus low photoanode activity. ${ }^{39,40}$ Conversely, rougher, more porous $\mathrm{IrO}_{2}$ catalyst films allow the electrolyte to contact both the catalyst and semiconductor, which shifts the relative positions of the $\mathrm{IrO}_{2}$ Fermi level and semiconductor conduction band minimum, facilitating hole extraction to the electrolyte and thus OER catalysis. ${ }^{39,40}$ We propose a similar effect in these silicon photoanodes: both photoanodes have some degree of cracking in the catalyst layer and thus have some silicon-electrolyte contact. Importantly, the $\mathrm{SrCl}_{2}: \mathrm{IrO}_{\mathbf{x}} \mid \mathrm{n}-\mathrm{Si}$ has a rougher surface with more cracks, causing more Si-electrolyte interaction than $\mathrm{IrO}_{\mathrm{x}} \mid \mathrm{n}-\mathrm{Si}$. This semiconductor-catalyst-electrolyte contact is hypothesized to improve hole transport across the interface in $\mathrm{SrCl}_{2}: \mathrm{IrO}_{\mathrm{x}} \mid \mathrm{n}-\mathrm{Si}$ compared to $\mathrm{IrO}_{\mathrm{x}} \mid \mathrm{n}-\mathrm{Si}$. 
State of the art photoanodes, such as those based on ultrathin coatings of ALD-deposited $\mathrm{TiO}_{2}$ on $\mathrm{Si}$, generate $0.5-0.6 \mathrm{~V}$ of photovoltage in acidic electrolyte. ${ }^{9,14,19-21,41,42}$ It is notable that the photovoltages reported here are in line with those of $\mathrm{TiO}_{2}$-protected photoanodes, but the fabrication scheme presented here is much simpler and less sensitive than the ALD procedures used in the field and does not need a silicon homojunction for photoactivity, which could allow for better integration with photocathodes.

\section{ii. Photoanode Stability}

In addition to high activity, an effective photoanode must also have long-term stability. We first measured the durability of the catalysts on degenerately doped silicon after an initial CV measurement and brief ( $\sim 30 \mathrm{~min})$ air exposure by performing one CV sweep followed by a 30 minute chronoamperometry (CA) measurement, repeated over 7 hours (Figure 4). The CA behavior was monitored at $1.57 \mathrm{~V}$ vs. RHE, the initial potential needed for $\mathrm{IrO}_{\mathrm{x}}$ to reach $10 \mathrm{~mA} / \mathrm{cm}^{2}$ in the first CV sweep. $\mathrm{SrCl}_{2}: \mathrm{IrO}_{\mathrm{x}}$ initially has $\sim 20 \%$ higher current than $\mathrm{IrO}_{\mathrm{x}}$ as seen in both the anodic CV sweeps and CA current during the first $30 \mathrm{~min}$ hold. However, after around $3 \mathrm{~h}$, the current densities of both catalysts decreased to nearly the same value, with $\mathrm{IrO}_{\mathrm{x}}$ losing $40 \%$ of its initial current density, and $\mathrm{SrCl}_{2}: \mathrm{IrO}_{\mathrm{x}}$ losing $60 \%$. After $3 \mathrm{~h}$ of testing, the current densities approach a stable value, and degradation is much slower than the initial rate. 

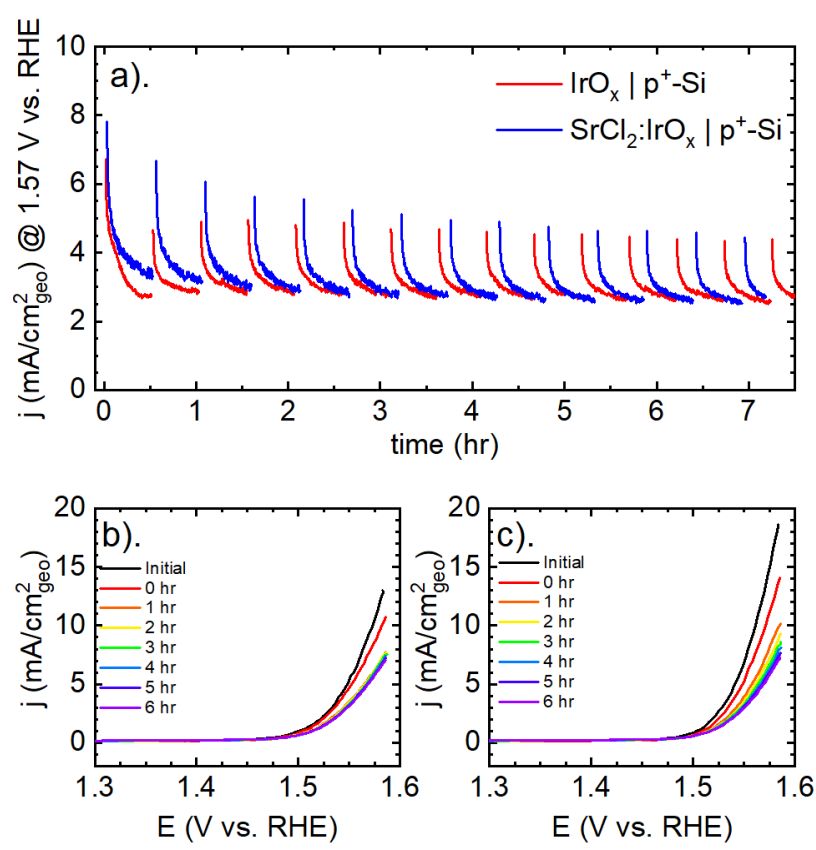

Figure 4. OER catalyst stability. Chronoamperometric testing of the catalysts on degenerately doped $\left(\mathrm{p}^{+}\right) \mathrm{Si}$ at $1.57 \mathrm{~V}$ vs. RHE (a). Anodic sweeps taken with a scan rate of $10 \mathrm{mV} / \mathrm{s}$ every $\sim 1$ hour for $\mathrm{IrO}_{\mathrm{x}}(\mathrm{b})$ and $\mathrm{SrCl}_{2}: \mathrm{IrO}_{\mathrm{x}}(\mathrm{c}) . \mathrm{SrCl}_{2}: \mathrm{IrO}_{\mathrm{x}}$ has improved activity compared to $\mathrm{IrO}_{\mathrm{x}}$ but the degradation rates are similar.

To investigate the stability of the photoanodes, we used a similar protocol to that used above for the OER catalyst stability: after an initial CV measurement and brief air exposure we measured a CV sweep followed by 30 minutes of chronoamperometry at $1.3 \mathrm{~V}$ vs. RHE, repeated over 4-20 hours (Figure 5). At a potential of $1.3 \mathrm{~V}$ vs. RHE, the current density is just below the light-limited current density and is the potential where the photoanode would generate its maximum power. ${ }^{1,6}$ The $\mathrm{IrO}_{\mathrm{x}}$ photoanode maintained its current density for approximately $4 \mathrm{~h}$, and actually increased from $17 \mathrm{~mA} / \mathrm{cm}^{2}$ to a peak of $19 \mathrm{~mA} / \mathrm{cm}^{2}$ after $3 \mathrm{~h}$ (Figure $5 \mathrm{a}$ ). This increase in photocurrent correlates with an increase in light-limited current density as seen in the LSVs (Figure 5b), from 
$26 \mathrm{~mA} / \mathrm{cm}^{2}$ to $32 \mathrm{~mA} / \mathrm{cm}^{2}$ after 9 hours of testing. The light-limited current density likely increases due to the $\mathrm{IrO}_{\mathrm{x}}$ film material degrading/delaminating (See Figure 6), thereby reducing parasitic light absorption in the catalyst layer. For the same photoanode, the onset potential observed in the LSVs continuously shifted to a more positive potential throughout the duration of the stability test (Figure 5b), indicating that the photovoltage started decreasing immediately. This loss in photovoltage contributes to decreasing current at $1.3 \mathrm{~V}$ vs. RHE. These two effects that occur with degradation of the $\mathrm{IrO}_{\mathrm{x}}$ catalyst and interface - decreased parasitic light absorption and decreased catalytic performance - combine to produce the observed photocurrent behavior. Namely, there is initially a slight increase in photocurrent during the first $3 \mathrm{~h}$ due to an increase in the light-limited current density. At later times, the photovoltage decreases enough to cause a rapid decrease in the current produced at $1.3 \mathrm{~V}$ vs. RHE.

On the other hand, the strontium chloride-modified photoanode was significantly less stable than the iridium oxide photoanode, with the photocurrent density decreasing almost immediately and losing $90 \%$ of its photocurrent after a $4 \mathrm{~h}$ potential hold at $1.3 \mathrm{~V}$ vs. RHE. (Figure $5 \mathrm{a}$ ). In the LSVs the onset potential decreased quickly (Figure 5c), indicating that there was a loss in the amount of photovoltage being generated and thus rapid degradation of the photoanode. While the lightlimited current density does increase slightly, the more rapid loss in photovoltage decreases the current density at $1.3 \mathrm{~V}$ vs. RHE measured in the CA. While neither photoanode exhibited longterm stability, $\mathrm{IrO}_{\mathrm{x}} \mid \mathrm{n}-\mathrm{Si}$ maintained a high current density at $1.3 \mathrm{~V}$ vs. RHE for $4 \mathrm{~h}$ before abrupt degradation. 

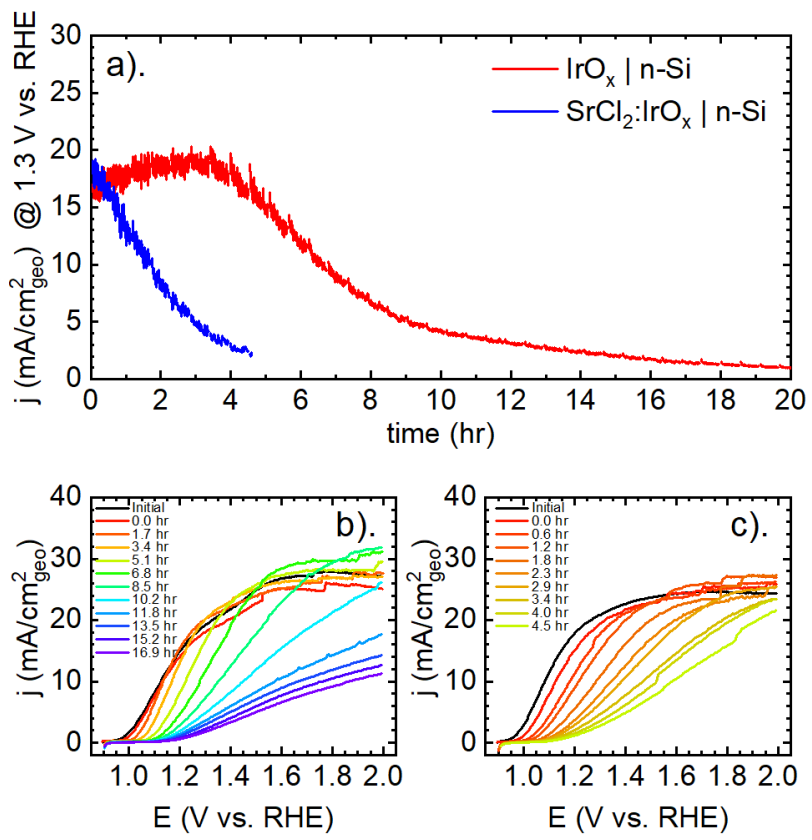

Figure 5: Photoanode stability. Chronoamperometric testing of the catalysts on degenerately doped Si at $1.3 \mathrm{~V}$ vs. RHE (a). A CV was measured with a scan rate of $10 \mathrm{mV} / \mathrm{s}$ every 30 minutes during the stability test, and selected anodic sweeps are shown for $\mathrm{IrO}_{\mathrm{x}}$ (b) and $\mathrm{SrCl}_{2}: \mathrm{IrO}_{\mathrm{x}}$ (c). $\mathrm{SrCl}_{2}: \mathrm{IrO}_{\mathrm{x}}$ degradation commences immediately, while $\mathrm{IrO}_{\mathrm{x}} \mid \mathrm{n}-\mathrm{Si}$ lasts for $4 \mathrm{~h}$ before degradation.

\section{Post-Test Characterization}

After the photoanode CA stability tests of 20 hours for $\mathrm{IrO}_{\mathrm{x}} \mid \mathrm{n}-\mathrm{Si}$ and 5 hours for $\mathrm{SrCl}_{2}: \mathrm{IrO}_{\mathrm{x}} \mid \mathrm{n}-$ $\mathrm{Si}$, structural characterization of the thin films was performed using SEM and AES to probe the failure mechanisms of the catalyst films (Figure 6). The SEM images of the $\mathrm{IrO}_{\mathrm{x}} \mid \mathrm{n}-\mathrm{Si}$ sample show large cracks that develop during testing and grow to be $0.5-5 \mu \mathrm{m}$ wide (Figure $6 \mathrm{a}$ ), and sections of the film appear to delaminate (Figure 6b). AES was measured at the specific points (Figure 6c) indicated on Figure 6b. The Auger spectra show that there are large regions where bare silicon is 
exposed (spot 2) as well as flakes of $\mathrm{IrO}_{\mathrm{x}}$ that appear to be delaminating (spot 3) from the main film (spot 1). Iridium has been shown in previous reports to have poor adhesion to $\mathrm{SiO}_{2} \cdot{ }^{41,42}$ Thus, we propose that the degradation pathway is likely an expansion of the initial film cracks followed by delamination as opposed to chemical dissolution.

$\mathrm{SrCl}_{2}: \mathrm{IrO}_{\mathrm{x}} \mid \mathrm{n}-\mathrm{Si}$ also showed extensive cracks on the order of $0.1-1 \mu \mathrm{m}$ wide, smaller than those in the $\mathrm{IrO}_{\mathrm{x}}$ coating (Figure 6d). These small-scale cracks match the size scale of the cracks in the as-deposited film (Figure 1f), so the degradation likely initiated at these defects. The striped morphology was retained after testing (Figure 6e), which originated from the phase segregation between $\mathrm{SrCl}_{2}$ and $\mathrm{IrO}_{\mathrm{x}}$. After the $\mathrm{SrCl}_{2}$ quickly dissolves (as seen in the XPS after three CVs, Figure S7), the 10-20 $\mu \mathrm{m}$-wide stripes remain as alternating thick and thin regions of $\mathrm{IrO}_{\mathrm{x}}($ Figure 6f, with points indicated on Figure 6e), which is seen in the AES data at point 5 (stronger Ir signal) and point 6 (weaker Ir signal) of Figure 6e. There are also regions of exposed Si (Figure 6e,f). None of the spectra show any $\mathrm{Sr}$ or $\mathrm{Cl}$, which is expected as there is very little $\mathrm{SrCl}_{2}$ detected by XPS after only $3 \mathrm{CVs}$ (Figure $\mathrm{S} 7$ ). $\mathrm{SrCl}_{2}: \mathrm{IrO}_{\mathrm{x}} \mid \mathrm{n}$-Si likely undergoes faster delamination than $\mathrm{IrO}_{\mathrm{x}} \mid \mathrm{n}-\mathrm{Si}$ as the strontium chloride-containing film initially has more cracks, is significantly less conformal, and has more electrolyte contact than the pure iridium oxide. This rapid delamination likely leads to the decreased PEC stability of $\mathrm{SrCl}_{2}: \mathrm{IrO}_{\mathbf{x}} \mid \mathrm{n}-\mathrm{Si}$ compared to $\mathrm{IrO}_{\mathrm{x}} \mid \mathrm{n}-\mathrm{Si}$ despite the higher initial activity. While film delamination limited photoanode stability, some catalyst material remained in contact with the Si after 4 and $20 \mathrm{~h}$ of PEC operation, for $\mathrm{SrCl}_{2}: \mathrm{IrO}_{\mathrm{x}} \mid \mathrm{n}-\mathrm{Si}$ and $\mathrm{IrO} \times \mathrm{x} \mid \mathrm{n}$ $\mathrm{Si}$, respectively, as seen by both the post-test SEM images and the continued photocurrent generation at the end of testing. Improving catalyst-semiconductor adhesion would likely improve the stability of these photoanodes and thus further the viability of these spin coating procedures 
for PEC systems. In addition, the advances this work demonstrate a means to improve the electronic interface between silicon and the catalyst by modifying $\mathrm{IrO}_{\mathrm{x}}$ with $\mathrm{SrCl}_{2}$, which further motivate efforts to stabilize these photoanodes. With improved stability, this tunable spin coating method offers a pathway to simplify photoelectrode fabrication processes.
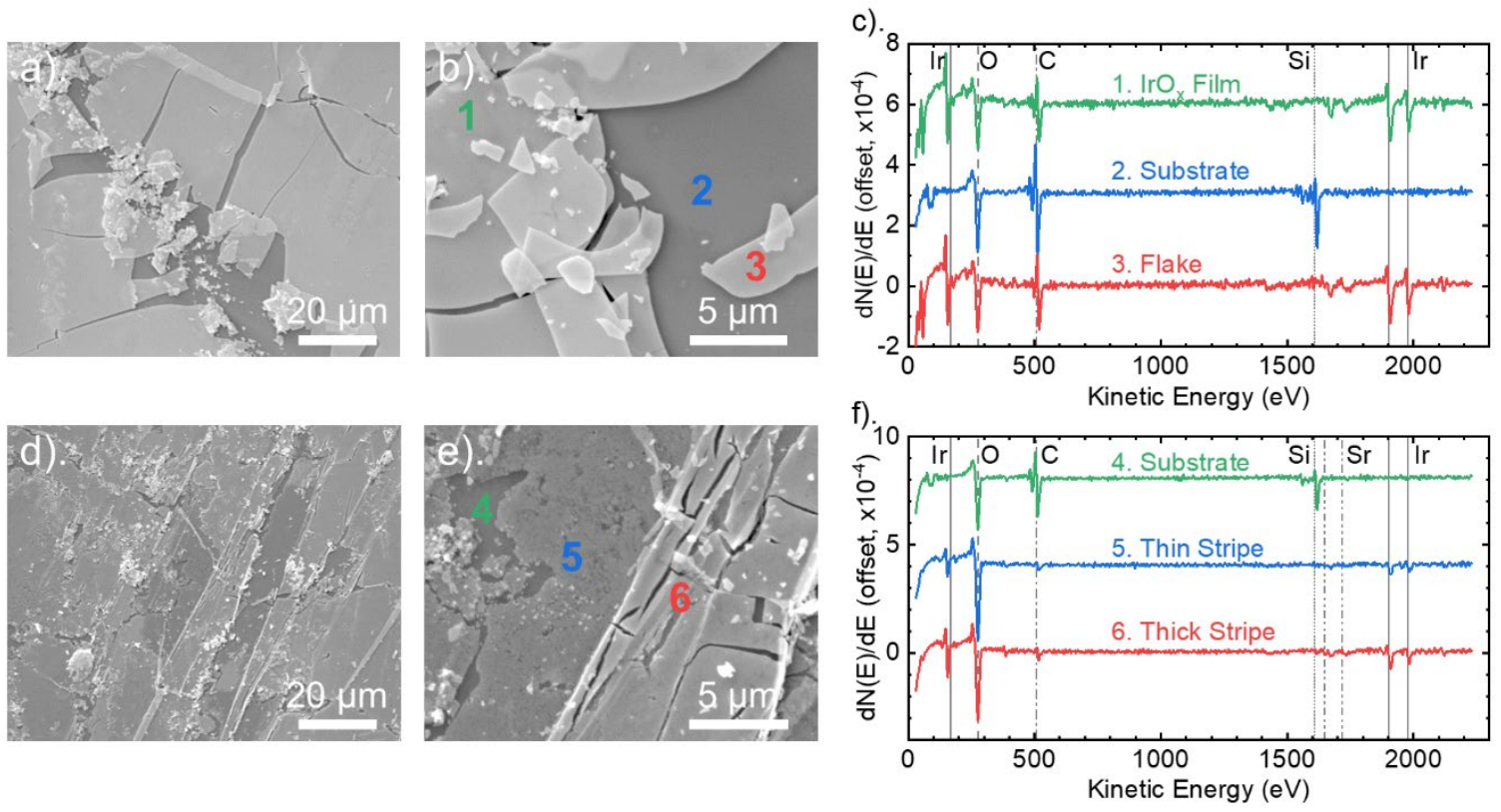

Figure 6. SEM and Auger spectroscopy post-stability testing for $\operatorname{IrO}_{x} \mid n-S i(a-c)$ and $\mathrm{SrCl}_{2}: \mathrm{IrO}_{x} \mid n-$ Si (d-f). Large-area SEM images (a,d) show cracking that develops during testing. Smaller-area SEM images $(b, e)$ are subsets of a,d. Auger spectra $(c, f)$ of selected points in the smaller SEM images were collected, with peaks for the relevant elements indicated with gray vertical lines. The points at which Auger analysis was performed are indicated with the relevant number in $b$ and $e$.

\section{Conclusion}

In this work a spin coating procedure was developed to prepare iridium oxide-based catalyst coatings onto silicon for use as photoanodes for PEC hydrogen production in acid. The photoanode with an $\mathrm{IrO}_{\mathrm{x}}$ catalyst formed a functioning photoanode, and the addition of strontium chloride to the catalyst coating improved PEC performance. In comparison to the $0.43 \mathrm{~V}$ of photovoltage 
generated by $\mathrm{IrO}_{\mathrm{x}} \mid \mathrm{n}-\mathrm{Si}$, the $\mathrm{SrCl}_{2}: \mathrm{IrO}_{\mathrm{x}} \mid \mathrm{n}-\mathrm{Si}$ photoanode prepared by this method demonstrated an improved photovoltage of $0.53 \mathrm{~V}$. These photoanodes exhibited comparable J-V performance to more conventional silicon photoanodes with a separate $\mathrm{ALD}$-deposited $\mathrm{TiO}_{2}$ protection layer ${ }^{9}, 19-$ ${ }^{21}$, thus demonstrating a pathway to reduce the number and intricacy of processing steps for future PEC water-splitting systems. By conducting ferrocyanide oxidation, we decoupled the interfacial charge transport from catalysis, indicating that the more heterogeneous film caused by strontium chloride precipitation improved the interfacial charge transport across the silicon-electrolyte interface. The stability of the catalysts and photoanodes were investigated, with the $\mathrm{IrO}_{\mathrm{x}}$ photoanodes lasting for 4 hours before degrading and the $\mathrm{SrCl}_{2}: \mathrm{IrO}_{\mathrm{x}}$ samples degrading within the first 4 hours. From post-testing characterization, consisting of AES, SEM, and XPS analysis, we determined that film cracking and delamination led to accelerated degradation. To improve photoelectrode longevity, attention must be given to catalyst adhesion. Due to their simple, tunable nature, the spin coating procedures developed here can be translated to other photoanode materials and tandem absorber systems. The beneficial charge transport properties of a rough, strontiumcontaining catalyst can also be leveraged in other PEC systems limited by poor electronic interfaces. Overall, this spin coating method has the potential to decrease PEC electrode fabrication cost and complexity compared to conventional CVD- and PVD-based photoanode fabrication while maintaining a high photovoltage, important characteristics when designing a tandem absorber system.

\section{Materials and Methods}

Photoanode Fabrication 
Single crystal phosphorous-doped n-type silicon (100) wafers with resistivity of 0.2-0.6 $\Omega$-cm were used as photoanode absorbers and are referred to here as n-Si $(100 \mathrm{~mm}$ diameter, $525 \mu \mathrm{m}$ thick, EL-CAT Inc.). Boron-doped p-type silicon (100) wafers with $<0.005 \Omega$-cm resistivity were used (100 mm diameter, $500 \mu \mathrm{m}$ thick, WRS Materials), referred to as $\mathrm{p}^{+}-\mathrm{Si}$, and were used as substrates to compare OER catalytic properties. All wafers were cleaned by sonication in soapy water, acetone, isopropanol, and deionized water prior to electrode fabrication and other otherwise were used as-received.

Catalyst layers on silicon substrates were prepared using an adapted version of a previouslyreported spin coating procedure. ${ }^{29-31}$ A Brewer Science CEE 200X spin coater was employed. The $\mathrm{IrO}_{\mathrm{x}}$ spin coating solution contained $20 \mathrm{~g} / \mathrm{L}(0.054 M)$ iridium acetate (99\%, American Elements) dissolved in ethanol (absolute, Acros). The solution for the $\mathrm{SrCl}_{2}: \mathrm{IrO}_{\mathrm{x}}$ film had an equimolar $(0.054 M)$ mixture of iridium acetate and strontium chloride (99.99\%, Acros) dissolved in 5\% v/v water (Millipore) in ethanol. For film deposition, $40 \mu \mathrm{L}$ of solution was applied while the substrate was rotating at $200 \mathrm{rpm}$ to maximize coverage. Then the substrate rotation rate was increased to $2000 \mathrm{rpm}$, accelerating at 200 revolutions $/ \mathrm{s}^{2}$, spinning for $60 \mathrm{~s}$, after which point there was a dry thin film on the Si surface. The chip was then heated on a $50{ }^{\circ} \mathrm{C}$ hotplate for 5 minutes to evaporate any residual solvent. Finally, the electrodes were calcined in a pre-heated furnace (Thermolyne) at $250{ }^{\circ} \mathrm{C}$ for two hours in ambient air.

Sibling samples were deposited on fused silica pieces (MTI Corporation, 10x10x1.0 mm, 1 side polished) and were used for crystallography measurements due to their amorphous nature. The spin coating and calcination procedure was the same as that for the silicon substrate samples. 


\section{Materials Characterization}

Cross-sectional and top-down scanning electron microscopy (SEM) (FEI Magellan 400 XHR) was used to measure film thickness and probe morphology. The native oxide thickness was estimated to be $1.8 \mathrm{~nm}$ with spectroscopic ellipsometry (Woollam M2000). Auger electron spectroscopy (AES) analysis was used to map the distribution of chemical constituents and was performed with a $10 \mathrm{kV} / 10 \mathrm{nA}$ electron gun beam (PHI 700 Scanning Auger Nanoprobe). X-ray diffraction (XRD) (Bruker Single Crystal D8 Venture) was performed in a grazing-incidence configuration with a 2D detector to probe the crystallinity of the catalyst films. X-ray photoelectron spectroscopy (XPS) (PHI 5000 Versaprobe 1) was used to identify the relative abundance of oxygen, iridium, strontium, chlorine, and sulfur, probing the $\mathrm{O} 1 \mathrm{~s}, \mathrm{Ir} 4 \mathrm{f}, \mathrm{Sr} 3 \mathrm{~d}, \mathrm{Cl} 2 \mathrm{p}$, and $\mathrm{S} 2 \mathrm{p}$ peaks. XPS spectra were calibrated to the $\mathrm{C} 1 \mathrm{~s}$ peak with a binding energy of $284.8 \mathrm{eV}$.

\section{Photoelectrochemical Testing}

Electrochemical measurements were performed in a standard three-electrode flat-faced quartz cell with a $\mathrm{Hg} / \mathrm{HgSO}_{4}$ (sat'd $\mathrm{K}_{2} \mathrm{SO}_{4}$ ) reference electrode and a Pt wire counter electrode. Electrochemical OER testing was conducted in $0.5 \mathrm{M}$ sulfuric acid (diluted from concentrated sulfuric acid 99.999\%, Sigma Aldrich) electrolyte. Oxygen gas was bubbled though the electrolyte, and a magnetic stir bar spinning at $350 \mathrm{rpm}$ underneath the working electrode was employed to enhance bubble detachment. All cyclic voltammetry was performed at a scan rate of $10 \mathrm{mV} / \mathrm{s}$. PEC testing was also conducted in electrolyte containing a reversible redox couple, $\mathrm{Fe}(\mathrm{CN}) 6^{3-} /$ $\mathrm{Fe}(\mathrm{CN})_{6}{ }^{4-}$. This electrolyte solution was prepared by dissolving $0.1 \mathrm{M} \mathrm{K}_{4} \mathrm{Fe}(\mathrm{CN})_{6} \bullet 6 \mathrm{H}_{2} \mathrm{O}\left(99 \%{ }^{+}\right.$, 
Acros) and $1 \mathrm{mM} \mathrm{K}_{3} \mathrm{Fe}(\mathrm{CN})_{6}\left(99 \%{ }^{+}\right.$, Acros) in water $(\mathrm{pH} 8.5)$. Ferrocyanide oxidation data was smoothed using a 10-point adjacent-averaging method in OriginPro 2018 software.

Photoelectrochemical measurements used a $100 \mathrm{~W}$ Xe arc lamp solar simulator (SunLite, Abet Technologies) calibrated to the AM $1.5 \mathrm{G}$ spectrum. ${ }^{43}$ A spectrometer (Jaz EL 200-XR1, Ocean Optics) was used to measure the flux of photons with energy exceeding the bandgap of silicon ( $\lambda$ $<1107 \mathrm{~nm}$ ), and the lamp was calibrated such that the total number of photons with $\lambda<1107 \mathrm{~nm}$ was equal to that of the AM $1.5 \mathrm{G}$ spectrum for $\lambda<1107 \mathrm{~nm}$.

Electrodes were prepared from the silicon wafers by forming an electrical contact on the backside of the silicon by scratching Ga-In eutectic ( $>99.99 \%$, Sigma-Aldrich) applied with a diamond scribe and attaching a wire to the Ga-In with carbon Electrodag (DAG-502, Ted Pella). The exposed wire and back/sides of the silicon were covered with epoxy (Hysol Loctite 9462). Electrode areas were measured with a digital photograph and analyzed using ImageJ, with areas ranging from $0.1-0.2 \mathrm{~cm}^{2}$.

\section{ASSOCIATED CONTENT}

\section{Supporting Information.}

The following files are available free of charge.

Additional material characterization (SEM, AES, XRD, XPS) and electrochemical characterization (open circuit potential measurements) (PDF)

\section{AUTHOR INFORMATION}




\section{Corresponding Author}

*Email: higgid2@mcmaster.ca (D.C.H.)

*Email: jaramillo@stanford.edu (T.F.J.)

\section{ACKNOWLEDGMENT}

This work was supported by the National Science Foundation (NSF) under NSF Center for Chemical Innovation CHE-1305124 for Solar Fuels. Part of this work was performed at the Stanford Nano Shared Facilities (SNSF) and nano@Stanford labs (SNF), supported by the National Science Foundation as part of the National Nanotechnology coordinated Infrastructure and under award ECCS-1542152. J.S. was supported by the Department of Defense (DoD) through the National Defense Science and Engineering Graduate Fellowship (NDSEG) Program and the Stanford University Diversifying Academia, Recruiting Excellence Doctoral Fellowship Program (DARE). D.W.P. and A.L.S. acknowledge the NSF through the Graduate Research Fellowship Program.

\section{REFERENCES}

(1) Seitz, L. C.; Chen, Z.; Forman, A. J.; Pinaud, B. A.; Benck, J. D.; Jaramillo, T. F. Modeling Practical Performance Limits of Photoelectrochemical Water Splitting Based on the Current State of Materials Research. ChemSusChem 2014, 7 (5), 1372-1385.

(2) Chu, S.; Li, W.; Yan, Y.; Hamann, T. W.; Shih, I.; Wang, D.; Mi, Z. Roadmap on Solar Water Splitting: Current Status and Future Prospects. Nano Futur. 2017, 1 (2).

(3) Walter, M. G.; Warren, E. L.; McKone, J. R.; Boettcher, S. W.; Mi, Q.; Santori, E. A.; Lewis, N. S. Solar Water Splitting Cells. Chem. Rev. 2010, 110 (11), 6446-6473. 
(4) Gray, H. B. Powering the Planet with Solar Fuel. Nat. Chem. 2009, 1, 7.

(5) Pinaud, B. A.; Benck, J. D.; Seitz, L. C.; Forman, A. J.; Chen, Z.; Deutsch, T. G.; James, B. D.; Baum, K. N.; Baum, G. N.; Ardo, S.; Wang, H.; Miller, E.; Jaramillo, T. F. Technical and Economic Feasibility of Centralized Facilities for Solar Hydrogen Production via Photocatalysis and Photoelectrochemistry. Energy Environ. Sci. 2013, 6 (7), 1983-2002.

(6) Bae, D.; Seger, B.; Vesborg, P. C. K.; Hansen, O.; Chorkendorff, I. Strategies for Stable Water Splitting via Protected Photoelectrodes. Chem. Soc. Rev. 2017, 46 (7), 1933-1954.

(7) Feng, J.; Gong, M.; Kenney, M. J.; Wu, J. Z.; Zhang, B.; Li, Y.; Dai, H. Nickel-Coated Silicon Photocathode for Water Splitting in Alkaline Electrolytes. Nano Res. 2015, 8 (5), 1577-1583.

(8) Laursen, A. B.; Pedersen, T.; Malacrida, P.; Seger, B.; Hansen, O.; Vesborg, P. C. K.; Chorkendorff, I. $\mathrm{MoS}_{2}$ - An Integrated Protective and Active Layer on n ${ }^{+} \mathrm{p}-\mathrm{Si}$ for Solar $\mathrm{H}_{2}$ Evolution. Phys. Chem. Chem. Phys. 2013, 15 (46), 20000-20004.

(9) Scheuermann, A. G.; Prange, J. D.; Gunji, M.; Chidsey, C. E. D.; McIntyre, P. C. Effects of Catalyst Material and Atomic Layer Deposited $\mathrm{TiO}_{2}$ Oxide Thickness on the Water Oxidation Performance of Metal-Insulator-Silicon Anodes. Energy Environ. Sci. 2013, 6 (8), 2487-2496.

(10) Mei, B.; Pedersen, T.; Malacrida, P.; Bae, D.; Frydendal, R.; Hansen, O.; Vesborg, P. C. K.; Seger, B.; Chorkendorff, I. Crystalline $\mathrm{TiO}_{2}$ : A Generic and Effective Electron-Conducting Protection Layer for Photoanodes and -Cathodes. J. Phys. Chem. C 2015, 119 (27), 1501915027. 
(11) Yoon, K.; Lee, J.-H.; Kang, J.; Kang, J.; Moody, M. J.; Hersam, M. C.; Lauhon, L. J. MetalFree Carbon-Based Nanomaterial Coatings Protect Silicon Photoanodes in Solar WaterSplitting. Nano Lett. 2016, 16 (12), 7370-7375.

(12) Nielander, A. C.; Bierman, M. J.; Petrone, N.; Strandwitz, N. C.; Ardo, S.; Yang, F.; Hone, J.; Lewis, N. S. Photoelectrochemical Behavior of N-Type Si(111) Electrodes Coated With a Single Layer of Graphene. J. Am. Chem. Soc. 2013, 135 (46), 17246-17249.

(13) Seger, B.; Castelli, I. E.; Vesborg, P. C. K.; Jacobsen, K. W.; Hansen, O.; Chorkendorff, I. 2-Photon Tandem Device for Water Splitting: Comparing Photocathode First versus Photoanode First Designs. Energy Environ. Sci. 2014, 7 (8), 2397-2413.

(14) Hendricks, O. L.; Scheuermann, A. G.; Schmidt, M.; Hurley, P. K.; McIntyre, P. C.; Chidsey, C. E. D. Isolating the Photovoltaic Junction: Atomic Layer Deposited $\mathrm{TiO}_{2}-\mathrm{RuO}_{2}$ Alloy Schottky Contacts for Silicon Photoanodes. ACS Appl. Mater. Interfaces 2016, 8 (36), $23763-23773$.

(15) Satterthwaite, P. F.; Scheuermann, A. G.; Hurley, P. K.; Chidsey, C. E. D.; McIntyre, P. C. Engineering Interfacial Silicon Dioxide for Improved Metal-Insulator-Semiconductor Silicon Photoanode Water Splitting Performance. ACS Appl. Mater. Interfaces 2016, 8 (20), $13140-13149$.

(16) Tan, C. S. S.; Kemp, K. W.; Braun, M.; Meng, A. C.; Tan, W.; Chidsey, C. E. D.; Ma, W.; Moghadam, F.; Mc Intyre, P. C. >10\% Solar-to-Hydrogen Efficiency Unassisted Water Splitting on ALD-Protected Silicon Heterojunction Solar Cells. Sustain. Energy Fuels 2019, $3(6), 1490-1500$. 
(17) Hu, S.; Lewis, N. S.; Ager, J. W.; Yang, J.; McKone, J. R.; Strandwitz, N. C. Thin-Film Materials for the Protection of Semiconducting Photoelectrodes in Solar-Fuel Generators. J. Phys. Chem. C 2015, 119 (43), 24201-24228.

(18) Nandjou, F.; Haussener, S. Degradation in Photoelectrochemical Devices: Review with an Illustrative Case Study. J. Phys. D. Appl. Phys. 2017, 50 (12), 124002.

(19) Scheuermann, A. G.; Lawrence, J. P.; Kemp, K. W.; Ito, T.; Walsh, A.; Chidsey, C. E. D.; Hurley, P. K.; McIntyre, P. C. Design Principles for Maximizing Photovoltage in MetalOxide-Protected Water-Splitting Photoanodes. Nat. Mater. 2016, 15 (1), 99-105.

(20) Scheuermann, A. G.; Chidsey, C. E. D.; Mcintyre, P. C. Understanding Photovoltage in Insulator-Protected Water Oxidation Half-Cells. J. Electrochem. Soc. 2016, 163 (3), 192200.

(21) Scheuermann, A. G.; Lawrence, J. P.; Meng, A. C.; Tang, K.; Hendricks, O. L.; Chidsey, C. E. D.; McIntyre, P. C. Titanium Oxide Crystallization and Interface Defect Passivation for High Performance Insulator-Protected Schottky Junction MIS Photoanodes. ACS Appl. Mater. Interfaces 2016, 8 (23), 14596-14603.

(22) Mei, B.; Seger, B.; Pedersen, T.; Malizia, M.; Hansen, O.; Chorkendorff, I.; Vesborg, P. C. K. Protection of $\mathrm{p}^{+}-\mathrm{n}-\mathrm{Si}$ Photoanodes by Sputter-Deposited $\mathrm{Ir} / \mathrm{IrO} \mathrm{x}_{\mathrm{x}}$ Thin Films. J. Phys. Chem. Lett. 2014, 5 (11), 1948-1952.

(23) Kibsgaard, J.; Chorkendorff, I. Considerations for the Scaling-up of Water Splitting Catalysts. Nat. Energy 2019, 4 (6), 430-433.

(24) McCrory, C. C. L.; Jung, S.; Ferrer, I. M.; Chatman, S. M.; Peters, J. C.; Jaramillo, T. F. 
Benchmarking Hydrogen Evolving Reaction and Oxygen Evolving Reaction Electrocatalysts for Solar Water Splitting Devices. J. Am. Chem. Soc. 2015, 137 (13), $4347-$ 4357.

Danilovic, N.; Subbaraman, R.; Chang, K.-C.; Chang, S. H.; Kang, Y. J.; Snyder, J.; Paulikas, A. P.; Strmcnik, D.; Kim, Y.-T.; Myers, D.; Stamenkovic, V. R.; Markovic, N. M. Activity-Stability Trends for the Oxygen Evolution Reaction on Monometallic Oxides in Acidic Environments. J. Phys. Chem. Lett. 2014, 5, 2474-2478.

(26) McCrory, C. C. L.; Jung, S.; Peters, J. C.; Jaramillo, T. F. Benchmarking Heterogeneous Electrocatalysts for the Oxygen Evolution Reaction. J. Am. Chem. Soc. 2013, 135 (45), $16977-16987$.

(27) Seitz, L. C.; Dickens, C. F.; Nishio, K.; Hikita, Y.; Montoya, J.; Doyle, A.; Kirk, C.; Vojvodic, A.; Hwang, H. Y.; Norskov, J. K.; Jaramillo, T. F. A Highly Active and Stable $\mathrm{IrO}_{x} / \mathrm{SrIrO}_{3}$ Catalyst for the Oxygen Evolution Reaction. Science 2016, 353 (6303), 10111014.

(28) Lee, K.; Osada, M.; Hwang, H. Y.; Hikita, Y. Oxygen Evolution Reaction Activity in $\mathrm{IrOx} / \mathrm{SrIrO}_{3}$ Catalysts: Correlations between Structural Parameters and the Catalytic Activity. J. Phys. Chem. Lett. 2019, 10, 1516-1522.

(29) Reier, T.; Weidinger, I.; Hildebrandt, P.; Kraehnert, R.; Strasser, P. Electrocatalytic Oxygen Evolution Reaction on Iridium Oxide Model Film Catalysts: Influence of Oxide Type and Catalyst Substrate Interactions. ECS Trans. 2013, 58 (2), 39-51.

(30) Reier, T.; Teschner, D.; Lunkenbein, T.; Bergmann, A.; Selve, S.; Kraehnert, R.; Schlögl, 
R.; Strasser, P. Electrocatalytic Oxygen Evolution on Iridium Oxide: Uncovering CatalystSubstrate Interactions and Active Iridium Oxide Species. J. Electrochem. Soc. 2014, 161 (9), F876-F882.

(31) Cherevko, S.; Reier, T.; Zeradjanin, A. R.; Pawolek, Z.; Strasser, P.; Mayrhofer, K. J. J. Stability of Nanostructured Iridium Oxide Electrocatalysts during Oxygen Evolution Reaction in Acidic Environment. Electrochem. commun. 2014, 48, 81-85.

(32) Gavini, S. N.; Vyas, S. N. Solvent Effects on Solubility and Dehydration of Strontium Chloride. J. Chem. Eng. Data 1979, 24 (4), 258-262.

(33) van Hardeveld, R. M.; Gunter, P. L. J.; van IJzendoorn, L. J.; Wieldraaijer, W.; Kuipers, E. W.; Niemantsverdriet, J. W. Deposition of Inorganic Salts from Solution on Flat Substrates by Spin-Coating: Theory, Quantification and Application to Model Catalysts. Appl. Surf. Sci. 1995, 84 (4), 339-346.

(34) Kuipers, E. W.; Laszlo, C.; Wieldraaijer, W. Deposition of Nanocrystals on Flat Supports by Spin-Coating. Catal. Letters 1993, 17 (1-2), 71-79.

(35) Troshin, P. A.; Hoppe, H.; Renz, J.; Egginger, M.; Mayorova, J. Y.; Goryachev, A. E.; Peregudov, A. S.; Lyubovskaya, R. N.; Gobsch, G.; Sariciftci, N. S.; Razumov, V. F. Material Solubility-Photovoltaic Performance Relationship in the Design of Novel Fullerene Derivatives for Bulk Heterojunction Solar Cells. Adv. Funct. Mater. 2009, 19 (5), 779-788.

(36) Scheuermann, A. G.; Lu, D. Q.; Ito, T.; Chidsey, C. E. D.; Mcintyre, P. C. The Effect of SPA-SiO 2 Tunnel Oxide Thickness for Metal-Insulator-Silicon Photoelectrochemical Cells. 
ECS Trans. 2014, 64 (9), 265-276.

(37) Chen, Y. W.; Prange, J. D.; Dühnen, S.; Park, Y.; Gunji, M.; Chidsey, C. E. D.; McIntyre, P. C. Atomic Layer-Deposited Tunnel Oxide Stabilizes Silicon Photoanodes for Water Oxidation. Nat. Mater. 2011, 10 (7), 539-544.

(38) Narkeviciute, I.; Jaramillo, T. F. Impact of Nanostructuring on the Photoelectrochemical Performance of Si/Ta $\mathrm{N}_{5}$ Nanowire Photoanodes. J. Phys. Chem. C 2017, 121, $27295-$ 27302.

(39) Ping, Y.; Goddard, W. A.; Galli, G. A. Energetics and Solvation Effects at the Photoanode/Catalyst Interface: Ohmic Contact versus Schottky Barrier. J. Am. Chem. Soc. 2015, $137(16), 5264-5267$.

(40) Spurgeon, J. M.; Velazquez, J. M.; McDowell, M. T. Improving $\mathrm{O}_{2}$ Production of $\mathrm{WO}_{3}$ Photoanodes with $\mathrm{IrO}_{2}$ in Acidic Aqueous Electrolyte. Phys. Chem. Chem. Phys. 2014, 16 (8), 3623-3631.

(41) Hendricks, O. L.; Tang-Kong, R.; Babadi, A. S.; McIntyre, P. C.; Chidsey, C. E. D. Atomic Layer Deposited $\mathrm{TiO}_{2}-\mathrm{IrO}_{\mathrm{x}}$ Alloys Enable Corrosion Resistant Water Oxidation on Silicon at High Photovoltage. Chem. Mater. 2019, 31 (1), 90-100.

(42) Tang-Kong, R.; Winter, R.; Brock, R.; Tracy, J.; Eizenberg, M.; Dauskardt, R. H.; McIntyre, P. C. The Role of Catalyst Adhesion in $\mathrm{ALD}-\mathrm{TiO}_{2}$ Protection of Water Splitting Silicon Anodes. ACS Appl. Mater. Interfaces 2018, 10 (43), 37103-37109.

(43) ASTM International. ASTM G173-03(2012) Standard Tables for Reference Solar Spectral Irradiances: Direct Normal and Hemispherical on $37^{\circ}$ Tilted Surface; West Conshohocken, 
PA, 2012. 